\title{
Resection of pleural implants in patients with lung cancer should remain the exception rather than the rule
}

\author{
Benny Weksler, MD, MBA
}

\author{
From the Division of Thoracic Surgery, University of Tennessee Health Science Center, Memphis, Tenn. \\ Disclosures: Dr Weksler is a Proctor for Intuitive Surgery. \\ Received for publication Oct 27, 2017; accepted for publication Oct 27, 2017; available ahead of print Jan 12 , \\ 2018. \\ Address for reprints: Benny Weksler, MD, MBA, Division of Thoracic Surgery, University of Tennessee Health \\ Science Center, 1325 Eastmoreland Ave, Ste 460, Memphis, TN 38104 (E-mail: bweksler@uthsc.edu). \\ J Thorac Cardiovasc Surg 2018;155:1207-8 \\ $0022-5223 / \$ 36.00$ \\ Copyright (C) 2017 by The American Association for Thoracic Surgery \\ https://doi.org/10.1016/j.jtcvs.2017.10.111
}

The eighth edition of the American Joint Commission on Cancer TNM classification for lung cancer classifies pleural implants or effusion as M1a disease. ${ }^{1}$ Pleural implants harbor a grim prognosis, with very few patients surviving 5 years after diagnosis. ${ }^{2}$ Several investigators have published reports regarding the potential survival advantage of resecting oligometastatic disease in patients with nonsmall cell lung carcinoma (NSCLC), ${ }^{3,4}$ and there have been a few reports purporting survival advantages when pleural implants are resected. ${ }^{5-7}$ Several of these reports precede the seventh edition of the American Joint Commission on Cancer classifications for lung cancer, which reclassified pleural implants as M1a disease rather than as T4 disease, ${ }^{8,9}$ and all of the published case series included only patients found to have pleural implants during definitive surgery while excluding patients diagnosed with pleural implants preoperatively. All of these studies are single-institution studies fraught with substantial selection bias, and applying their conclusions to day-to-day clinical practice is difficult. Most surgeons will not resect either the primary tumor or the pleural implants in patients with stage M1a NSCLC, preferring to treat them with other modalities.

$\mathrm{Li}$ and colleagues ${ }^{10}$ revisit the topic of resection in patients with pleural implants. They retrospectively review their experience over 8 years with patients with pleural metastases detected at surgery. They identified 43 patients with pleural implants that were found during definitive, minimally invasive, video-assisted thoracoscopic surgery (VATS) resection for NSCLC. The majority of patients were nonsmokers $(74 \%)$ and women $(63 \%)$, and their cancers were clinically classified as T1 $(53 \%)$ or N0 $(69 \%)$ before surgery. In 30 patients, the pleural implants were resected together with the primary tumor. In the remaining 13 patients, the VATS resection was aborted, and only a pleural biopsy was performed. Three-year progression-free survival and overall survival for the whole cohort were

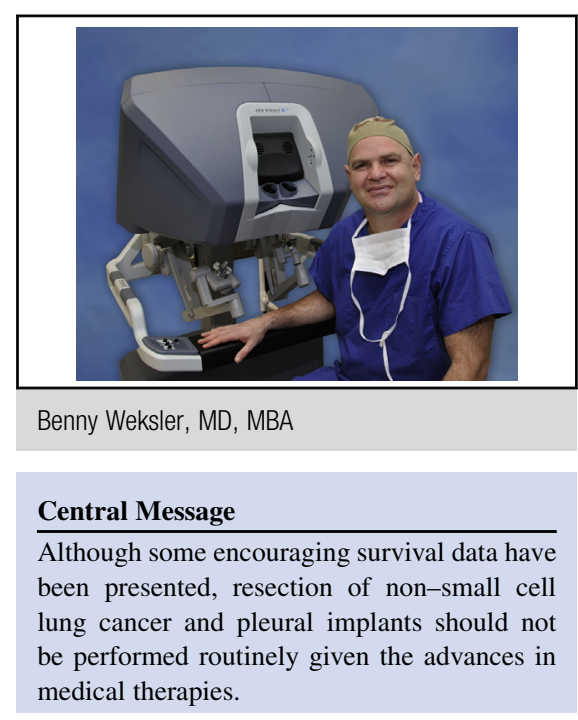

See Article page 1238 .

quite reasonable at $32.5 \%$ and $69.2 \%$, respectively. Progression-free survival was better in the resection group than in the group with aborted resections $(44.5 \%$ vs $0 \%$ at 3 years). Overall survival was also better in the resection group (64 months vs 35 months). As in previous studies, there are clear selection biases in the current study. Patients who underwent resection had lower $\mathrm{T}$ classification and were more likely to have limited pleural disease. The choice of procedure was entirely up to the surgeon, and it is logical to assume that surgeons were more reluctant to complete the planned VATS resection in patients with more advanced pleural disease. Finally, it is hard to assess whether the good results in the resection group were due to resection of the primary tumor and the pleural implants, or due to more favorable tumor biology.

There is no question that the field of immunotherapy for advanced lung cancer (and all cancers) will continue to evolve. Recent work on monoclonal antibodies that block the programmed death ligand 1 in patients with locally advanced NSCLC shows promising results. ${ }^{11}$ In light of advances in medical therapy, should thoracic surgeons routinely resect NSCLC with pleural implants? I believe the evidence is weak to justify routine resection. Potentially, in patients with very localized pleural disease and a good risk profile, a surgeon may be justified in completing 
resection of the primary tumor and pleural implants. However, this should be the exception rather than the rule.

\section{References}

1. Rami-Porta R, Asamura H, Travis WD, Rusch VW. Lung. In: American Joint Commission on Cancer. American Joint Commission on Cancer Staging Manual. 8th ed. New York, NY: Springer; 2017:431-56.

2. Eberhardt WE, Mitchell A, Crowley J, Kondo H, Kim YT, Turrisi A III, et al. The IASLC Lung Cancer Staging Project: proposals for the revision of the M descriptors in the forthcoming eighth edition of the TNM classification of lung cancer. J Thorac Oncol. 2015;10:1515-22.

3. Griffioen GH, Toguri D, Dahele M, Warner A, De Haan PF, Rodrigues GB, et al. Radical treatment of synchronous oligometastatic non-small cell lung carcinoma (NSCLC): patient outcomes and prognostic factors. Lung Cancer. 2013;82:95-102.

4. Tönnies M, Pfannschmidt J, Bauer TT, Kollmeier J, Tönnies S, Kaiser D. Metastasectomy for synchronous solitary non-small cell lung cancer metastases. Ann Thorac Surg. 2014;98:249-56.

5. Okamoto T, Iwata T, Mizobuchi T, Hoshino H, Moriya Y, Yoshida S, et al. Pulmonary resection for lung cancer with malignant pleural disease first detected at thoracotomy. Eur J Cardiothorac Surg. 2012;41:25-30.
6. Liu T, Liu H, Wang G, Zhang C, Liu B. Survival of M1a non-small cell lung cancer treated surgically: A retrospective single-center study. Thorac Cardiovasc Surg. 2015;63:577-82.

7. Yun JK, Kim MA, Choi CM, Choi SH, Kim YH, Kim DK, et al. Surgical outcomes after pulmonary resection for non-small cell lung cancer with localized pleural seeding first detected during surgery. Thorac Cardiovasc Surg. 2018;155:1238-49.

8. Sawabata N, Matsumura A, Motohiro A, Osaka Y, Gennga K, Fukai S, et al. Malignant minor pleural effusion detected on thoracotomy for patients with nonsmall cell lung cancer: is tumor resection beneficial for prognosis? Ann Thorac Surg. 2002;73:412-5.

9. Mordant P, Arame A, Foucault C, Dujon A, Le Pimpec Barthes F, Riquet M. Surgery for metastatic pleural extension of non-small-cell lung cancer. Eur J Cardiothorac Surg. 2011;40:1444-9.

10. Li C, Kuo SW, Hsu HH, Lin MW, Chen JS. Lung adenocarcinoma with intraoperatively 1 diagnosed pleural seeding: is main tumor resection beneficial for prognosis? J Thorac Cardiovasc Surg. 2017 [Epub ahead of print].

11. Antonia SJ, Villegas A, Daniel D, Vicente D, Murakami S, Hui R, et al. Durvalumab after chemoradiotherapy in stage III non-small-cell lung cancer. New Engl J Med. 2017;377:1919-29. 